Journal of Epidemiology and Public Health (2019), 4(3): 180-182

https://doi.org/10.26911/jepublichealth.2019.04.03.04

\title{
The Correlation of Age with Uric Acid in Kadipiro, Surakarta
}

\author{
Yeti Nurhayati'), Tresia Umarianti²) \\ 1)Nursery Program, School of Health Sciences Kusuma Husada, Surakarta \\ 2)Diploma III of Midwifery, School of Health Sciences Kusuma Husada, Surakarta
}

\begin{abstract}
Background: Uric acid is the final product of purine metabolism. Purines (adenine and guanine) are nucleic acid contituents. Purine rotation occurs continuously in the body along with the synthesis and decomposition of DNA and RNA, although there is no intake of purine, a substantial amount of uric acid will still be formed. Uric acid is synthesized mainly in the liver by the xanthine oxidase enzyme. This study aimed to examine the correlation of age with uric acid.

Subjects and method: This was a cross sectional study conducted in Gambirsari Health Center, Kadipiro Village, Mojosongo, Surakarta, Central Java. A sample of 50 gout patients was selected by purposive sampling. The dependent variable was uric acid. The independent variable was age. The data were analyzed by Pearson correlation.
\end{abstract}

Results: There was a correlation between age and uric acid $(r=0.37 ; p=0.009)$.

Conclusion: There is a correlation between age and uric acid.

Keywords: gout, age, uric acid

Correspondence:

Yeti Nurhayati. Nursery Study Program, School of Health Sciences Kusuma Husada, Surakarta, Central Java. Email: yeti_nurhayati234@yahoo.com.

\section{BACKGROUND}

Uric acid is the final product of purine metabolism (adenine and guanine) is a nucleic acid constituent. Purine rotation occurs continuously in the body along with the synthesis and decomposition of DNA and RNA, although there is no intake of purines, purines will still form substantial amounts of uric acid, i.e. uric acid is synthesized mainly in the liver formed by the enzyme xantine oxydase (Kurniawan, 2015).

The first gout was studied by a doctor who was a Dutch national named Van der Host in 1935, from the results of his study, it was found that 15 patients suffering from gout arthritis generally occur in the area of Central Java (Sudoyo et al, 2006).

A study by Tjokroprawiro (2007), the prevalence of gout arthritis in the population in the USA is estimated at 13.6/
100,000 population. In 2010, gout arthritis was associated as a leading cause of death from cardiovascular disease (Kuo et al, 2010). Meanwhile, other studies state that gout arthritis in Indonesia, ranks second after osteoarthritis (Dalimartha, 2008).

The purpose of this study was to analyze the relationship between age and the incidence of gout

\section{SUBJECTS AND METHOD \\ 1. Study Design \\ This was a cross sectional study conducted in Gambirsari Health Center, Kadipiro, Surakarta, Central Java, in May 2018.}

\section{Study Sample}

A sample of 50 gout patients was selected by purposive sampling.

\section{Study Variables}

The dependent variable was uric acid. The independent variable was age. 


\section{Data Analysis}

The data were analyzed by Pearson correlation.

\section{RESULTS}

1. Univariate Analysis

Table 1 showed sample characteristics. Table 1 showed that the average age of the

Table 1. Sample Characteristics

\begin{tabular}{lcccccc}
\hline Characteristics & N & Mean & Median & SD & Min. & Max. \\
\hline Age & 50 & 54.08 & 53.00 & 11.43 & 35 & 85 \\
Uric Acid & 50 & 8.35 & 7.75 & 2.17 & 6.2 & 19.8 \\
\hline
\end{tabular}

\section{Bivariate Analysis}

Table 2 showed the relationship between age and urine acid level. Table 2 showed sample was 54 years old. Minimum and maximum age were $35-85$ years old. The average of uric acid was $8.3 \mathrm{mg} / \mathrm{dl}$, the median was $7.7 \mathrm{mg} / \mathrm{dl}$, the minimum number of uric acid was $6.2 \mathrm{mg} / \mathrm{dl}$ and maximum $19.8 \mathrm{mg} / \mathrm{dl}$.

Table 2. Relationship between age and uric acid level using Pearson correlation

\begin{tabular}{lcc}
\hline Independent Variable & $\mathbf{r}$ & $\mathbf{p}$ \\
\hline Age & 0.37 & 0.009 \\
\hline
\end{tabular}

\section{DISCUSSION}

The results of this study did not identify the dietary patterns of daily activities of respondents. From the results of observations at the study site, respondents have not received information about healthy, lowpurine diets. In addition, menoupause factors were also not raised in this study.

The study by Setyoningsih (2009) reported that at the age above 40 years old, people usually begin to have an increase in uric acid levels that occurred due to decreased kidney function in the process of excretion of metabolic waste in the body characterized by high levels of urea and creatinine. Other factors that caused an increase in uric acid levels at the age above 40 years old were obesity, high blood pressure, abnormal blood cholesterol levels, consuming alcohol. In obese people (BMI> $25 \mathrm{~kg} / \mathrm{m} 2$ ), leptin levels in the body would increase. Leptin was a helical protein secreted by adipose tissue. Leptin level increased with uric acid in the blood. This was due to a disruption of the uric acid that age was positively associated with urine acid and it was statistically significant ( $\mathrm{r}=0.37 ; \mathrm{p}=0.009$ ). reabsorption process in the kidneys (Choi, 2008).

The study by Choi (2008) conducted for 12 years with a total of 730 study subjects on the incidence of uric acid, reported that in male with a $\mathrm{BMI} \geq 23$ had a greater risk of high uric acid level. For men who gain weight at age 21 years or above, have a higher risk of uric acid than men who maintain their normal weight (Choi, 2008).

\section{ACKNOWLEDMENT}

With the implementation of this research, the author would like to thank to: Directorate of Research and Community Service, Directorate General of Strengthening Research and Development at the Ministry of Research, Technology and Higher Education which has provided research grants for the 2018 budget year.

\section{REFERENCES}

Choi HK, Mount DB, Reginato AM (2005). Patogenesis of gout. Annals of Inter- 
Journal of Epidemiology and Public Health (2019), 4(3): 180-182

https://doi.org/10.26911/jepublichealth.2019.04.03.04

nal Medicine. 143(7): 499-516. Available at: http://www.internalmedicine.com.

Choi HK, Karen A, Elizabeth WK, Gary C (2008). Obesity, weight change, hypertension, diuretic use and risk of gout in men. Archives of Internal Medicine. 165: 742-748. Available at: http://www.internal-medicine.com.

Dalimartha (2008). Resep tumbuhan Obat Untuk Asam Urat. Jakarta: Penebar Swadaya.

Kurniawan FB (2015). Kimia Klinik: Praktikum Analisis Kesehatan. Jakarta: EGC.
Kuo et al. (2010). Gout: An independent risk factor for allcause and cardiovascular mortality, Rheumatology Oxford, 49(1): 141-146.

Setyoningsih R (2009). Faktor-faktor yang berhubungan dengan kejadian hiperurisemia pada pasien rawat jalan RSUP Dr.Kariadi Semarang. http://eprints.undip.ac.id/25234/1/237_Rin i_Setyoningsih_G2Co05301.pdf.

Sudoyo et al. (2006). Buku ajar ilmu penyakit dalam. Jilid III, Edisi IV, Jakarta: FK-UI

Tjokroprawiro A (2007). Ilmu penyakit dalam. Surabaya: Airlangga University Press. 